\title{
Role of Conservative Management in Treating Ameloblastoma of Jaw Bones: A Review of Literature
}

\author{
Prasanthi Gurram $^{1 *}$, Pooja Narayanan ${ }^{2 *}$, Saravanan Chandran³, Lakshmi Rathan AC ${ }^{1}$ \\ ${ }^{1}$ Associate Professor, Department of Oral and Maxillofacial Surgery, SRM Kattankulathur Dental College and \\ Hospital, SRM Institute of Science and Technology, India \\ ${ }^{2}$ Junior Trainee, Department of Oral and Maxillofacial Surgery, SRM Kattankulathur Dental College and \\ Hospital, SRM Institute of Science and Technology, India \\ ${ }^{3}$ Professor, Department of Oral and Maxillofacial Surgery, SRM Kattankulathur Dental College and Hospital, \\ SRM Institute of Science and Technology, India \\ *Corresponding Author: Prashanthi Gurram, Associate Professor, Department of Oral and Maxillofacial \\ Surgery, SRM Kattankulathur Dental College and Hospital, SRM Institute of Science and Technology, India; \\ Email: prashang@srmist.edu.in
}

Received Date: 17-11-2021; Accepted Date: 10-01-2022; Published Date: 18-01-2022

Copyright $^{\odot} 2022$ by Gurram P, et al. All rights reserved. This is an open access article distributed under the terms of the Creative Commons Attribution License, which permits unrestricted use, distribution and reproduction in any medium, provided the original author and source are credited.

\begin{abstract}
Objective: The objective of this review article is to identify the role of conservative management and conditions which could produce positive outcomes in a recurrent tumor like Ameloblastoma of the jaw bones.

Method: Data was collected from the search engine PUBMED, MEDLINE, etc. Most of the articles collected have been published between the years 2010-2020.

Result: 56 articles were selected overall and 49 have been selected after considering the exclusion criteria. The exclusion criteria include any non-original articles, articles that include other types of Odontogenic tumors, evidence containing animal studies etc. The articles selected range from review papers, short reports, retrospective reviews and/ or studies to systematic reviews and research papers.

Conclusion: The current review paper suggests that Conservative techniques like Enucleation/ Marsupialization along with adjuvant procedures like Chemical cauterization and Dredging techniques have shown promising results in certain kinds of Unicystic and minimally invasive Solid / Multicystic Ameloblastoma.
\end{abstract}




\section{Keywords}

Ameloblastoma; Recurrence Rate; Radical Resection; Conservative Management; Unicystic Ameloblastoma

\section{Introduction}

Tumours of the maxillofacial skeleton are broadly grouped into odontogenic and nonodontogenic, which may be benign or malignant in nature. In 2005 the World Health Organization (WHO) described Ameloblastoma as a benign, locally invasive, polymorphic neoplasm that consists of proliferating odontogenic epithelium lying in a fibrous stroma [1]. Ameloblastoma accounts for $1 \%$ of all oral tumours and $9-11 \%$ of all odontogenic tumours [2]. In $80 \%$ of the cases, it is localized in the mandible and in $20 \%$ cases; it affects the maxilla [3]. It occurs in all the age groups but the peak incidence is in the third and fourth decades with no gender predilection [4-6].

Ameloblastoma is histologically classified into 4 groups

1. Solid/Multicystic

2. Peripheral/ Extraosseous

3. Unicystic (UA)

4. Desmoplastic (DA) [1].

It presents as a painless bony swelling or as an incidental finding on radiological examination. It can appear either as a unilocular or a multilocular lesion on radiographic findings [7]. The regimen for treating ameloblastoma still remains a dilemma for surgeons. The selection of treatment depends on macroscopic and histological type, age of the patient, behavior of the lesion, recurrence rate, etc. The conventional method of treating Ameloblastoma is wide local excision which is proved to have a reduced recurrence rate of $0-21 \%$ [2]. Radical resection, when employed results in functional abnormalities and local deformities results in a compromised living quality in an individual. In contrast, conservative management causes less structural and functional impairment and optimises the patient's quality of life. Therefore, it can be considered as an alternative to radical approach when appropriate. Conservative treatment modalities involve enucleation, marsupialization or curettage along with adjunctive therapies [8-12]. In view of the higher recurrence rate of Ameloblastoma following conservative management $(29.3 \%$ - 93\%), a long term follow-up is mandatory [2,10]. The present review aims to outline the role of conservative management and its feasibility in treating this pathology. 


\section{Materials and Methods}

Data was collected from the search engine PUBMED, MEDLINE, etc. All the articles selected are original international articles. Keywords like conservative management of Ameloblastoma, surgical management of Ameloblastoma, Dredging method, Use of Carnoy's in Ameloblastoma, etc, were used. Most of the articles collected have been published between the years 2010-2020 with an available summary and in humans were included (Table 1).

\begin{tabular}{|c|c|c|c|c|c|c|}
\hline $\begin{array}{l}\text { Author, } \\
\text { Year }\end{array}$ & $\begin{array}{c}\text { No of } \\
\text { patients }\end{array}$ & $\begin{array}{c}\text { Male }(\mathrm{M}), \\
\text { Female }(\mathrm{F}) \\
\text { patients }\end{array}$ & $\begin{array}{c}\text { Type of } \\
\text { Ameloblastoma }\end{array}$ & Treatment & $\begin{array}{c}\text { Follow } \\
\text { up }\end{array}$ & $\begin{array}{c}\text { Recurrence } \\
\text { rate }\end{array}$ \\
\hline \multirow{2}{*}{$\begin{array}{l}\text { R. A. Stout, } \\
1962\end{array}$} & \multirow[t]{2}{*}{6} & \multirow[t]{2}{*}{$2 \mathrm{M}, 4 \mathrm{~F}$} & \multirow{2}{*}{$\begin{array}{l}\text { Ameloblastoma- } \\
\text { multilocular } \\
\text { lesion, } \\
\text { Unilocular } \\
\text { radicular cyst }\end{array}$} & $\begin{array}{l}\text { Conservative: } \\
\text { Marsupialisation, } \\
\text { Enucleation }\end{array}$ & \multirow{2}{*}{$\begin{array}{c}8 \\
\text { months } \\
\text { to } 12 \\
\text { years }\end{array}$} & \multirow{2}{*}{$\begin{array}{l}\text { Primary and } \\
\text { secondary } \\
\text { recurrence in } \\
1 \text { patient }\end{array}$} \\
\hline & & & & $\begin{array}{ll}\text { Radical: } & \text { Enbloc, } \\
\text { Marginal } & \end{array}$ & & \\
\hline Curi, 1997 & 36 & $18 \mathrm{M}, 18 \mathrm{~F}$ & $\begin{array}{c}\text { Solid } \\
\text { Ameloblastoma }\end{array}$ & $\begin{array}{l}\text { Liquid Nitrogen } \\
\text { Cryosurgery }\end{array}$ & $\begin{array}{c}14 \\
\text { months }\end{array}$ & 5 \\
\hline \multirow{3}{*}{$\begin{array}{c}\text { Takahashi, } \\
1998\end{array}$} & \multirow{3}{*}{6} & \multirow{3}{*}{$3 \mathrm{M}, 3 \mathrm{~F}$} & \multirow[t]{3}{*}{ UA, Multicystic } & \multirow{3}{*}{$\begin{array}{l}\text { Curettage, curettage } \\
+ \text { marsupialization, } \\
\text { curettage with } \\
\text { apicotomy, }\end{array}$} & \multirow{3}{*}{$\begin{array}{l}5-12 \\
\text { years }\end{array}$} & Primary: 4 \\
\hline & & & & & & Secondary: 3 \\
\hline & & & & & & Tertiary: 1 \\
\hline \multirow{3}{*}{ Pizer, 2002} & \multirow{3}{*}{1} & \multirow{3}{*}{ M } & \multirow[t]{3}{*}{$\begin{array}{c}\text { Unicystic } \\
\text { Ameloblastoma }\end{array}$} & $\begin{array}{l}\text { Enucleation } \\
\text { primarily }\end{array}$ & \multirow{3}{*}{$\begin{array}{c}15 \\
\text { years }\end{array}$} & $\begin{array}{l}\text { Primary: } 4 \\
\text { years, }\end{array}$ \\
\hline & & & & $\begin{array}{l}\text { Excision } \\
\text { secondary, }\end{array}$ & & $\begin{array}{c}\text { Secondary } \\
\text { recurrence: } 4 \\
\text { years }\end{array}$ \\
\hline & & & & Resection of tertiary & & \\
\hline
\end{tabular}




\begin{tabular}{|c|c|c|c|c|c|c|}
\hline $\begin{array}{l}\text { Chapelle, } \\
2004\end{array}$ & 19 & $13 \mathrm{M}, 6 \mathrm{~F}$ & UA, multilocular & $\begin{array}{l}\text { Enucleation, } \\
\text { Enucleation } \\
\text { Carnoy's solution, } \\
\text { resection }\end{array}$ & $\begin{array}{l}1-20 \\
\text { years }\end{array}$ & 5 \\
\hline $\begin{array}{l}\text { Arotiba, } \\
2005\end{array}$ & 79 & $45 \mathrm{M}, 34 \mathrm{~F}$ & $\begin{array}{l}\text { UA, Multicystic, } \\
\text { solid }\end{array}$ & $\begin{array}{l}\text { Enucleation, } \\
\text { resection }\end{array}$ & $\begin{array}{c}12 \\
\text { months } \\
\text { to } 4 \\
\text { years }\end{array}$ & - \\
\hline \multirow{3}{*}{$\begin{array}{l}\text { Huang, } \\
2007\end{array}$} & \multirow{3}{*}{15} & \multirow{3}{*}{$9 \mathrm{M}, 6 \mathrm{~F}$} & UA-8 & $\begin{array}{l}\text { Enucleation } \\
+ \text { Peripheral } \\
\text { ostectomy, }\end{array}$ & \multirow{3}{*}{$\begin{array}{l}2-17 \\
\text { years }\end{array}$} & Primary: 3 \\
\hline & & & Solid- 4 & $\begin{array}{l}\text { Decompression }+ \\
\text { Enucleation } \\
+ \text { Peripheral } \\
\text { ostectomy, } \\
\text { segmental resection } \\
\text { with immediate iliac } \\
\text { bone graft }\end{array}$ & & Secondary: 1 \\
\hline & & & Multicystic-3 & & & Tertiary: 1 \\
\hline \multirow{2}{*}{$\begin{array}{l}\text { Zhang, } \\
2009\end{array}$} & \multirow[t]{2}{*}{37} & \multirow[t]{2}{*}{$23 \mathrm{M}, 14 \mathrm{~F}$} & Solid- 28 & $\begin{array}{l}\text { Conservative- } 29 \\
\text { (7UA, } 22 \text { solid) }- \\
\text { curettage, } \\
\text { curettage+ cautery } \\
\text { or decompression }\end{array}$ & \multirow{2}{*}{$\begin{array}{l}\quad 3 \\
\text { months } \\
\text { to } 6 \\
\text { years }\end{array}$} & 10 primary \\
\hline & & & UA-9 & $\begin{array}{l}\text { Radical- } 8 \text { - } \\
\text { segmental or } \\
\text { hemimandibulecto } \\
\text { my and iliac grafts. }\end{array}$ & & 1 secondary \\
\hline Sadat, 2011 & $24 / 88$ & $10 \mathrm{M}, 14 \mathrm{~F}$ & Ameloblastoma & Dredging- 24 & - & Primary: 3 \\
\hline \multirow{2}{*}{$\begin{array}{l}\text { Carneiro, } \\
2012\end{array}$} & \multirow[t]{2}{*}{10} & \multirow[t]{2}{*}{$5 \mathrm{M}, 5 \mathrm{~F}$} & Solid- 5 & \multirow{2}{*}{$\begin{array}{l}\text { Gas combination } \\
\text { cryosurgery }\end{array}$} & \multirow{2}{*}{$\begin{array}{c}60.5 \\
\text { months }\end{array}$} & \multirow[b]{2}{*}{ - } \\
\hline & & & UA- 5 & & & \\
\hline $\begin{array}{c}\text { Tomita, } \\
2012\end{array}$ & 1 & $\mathrm{~F}$ & UA & $\begin{array}{l}\text { Marsupialisation+ } \\
\text { enucleation }+ \\
\text { extraction of } 3^{\text {rd }} \\
\text { molar }\end{array}$ & $\begin{array}{c}10 \\
\text { years }\end{array}$ & - \\
\hline
\end{tabular}




\begin{tabular}{|c|c|c|c|c|c|c|}
\hline Sano, 2013 & 1 & $\mathrm{~F}$ & UA, Luminal & $\begin{array}{l}\text { Marsupialization }+ \\
\text { Enucleation }\end{array}$ & 5 years & - \\
\hline \multirow{3}{*}{$\begin{array}{c}\text { Hasegawa, } \\
2013\end{array}$} & \multirow[t]{3}{*}{23} & \multirow[t]{3}{*}{$12 \mathrm{M}, 11 \mathrm{~F}$} & \multirow{3}{*}{$\begin{array}{c}\text { UA, } \\
\text { solid/Multicystic }\end{array}$} & $\begin{array}{ll}\text { Enucleation } & + \\
\text { marsupialization } & \end{array}$ & \multirow{3}{*}{$\begin{array}{c}8 \\
\text { months } \\
\text { to } 5 \\
\text { years }\end{array}$} & \multirow{3}{*}{$48.70 \%$} \\
\hline & & & & $\begin{array}{l}\text { Enucleation } \\
\text { +curettage }\end{array}$ & & \\
\hline & & & & Enucleation only & & \\
\hline $\begin{array}{l}\text { De Paulo, } \\
2014\end{array}$ & 1 & $\mathrm{~F}$ & UA & $\begin{array}{l}\text { Marsupialization+ } \\
\text { enucleation } \\
\text { Peripheral } \\
\text { Ostectomy }\end{array}$ & $\begin{array}{c}36 \\
\text { months }\end{array}$ & - \\
\hline $\begin{array}{l}\text { Borello, } \\
2016\end{array}$ & 1 & $\mathrm{~F}$ & $\begin{array}{c}\text { Peripheral } \\
\text { Ameloblastoma }\end{array}$ & Excisional Biopsy & 1year & - \\
\hline $\begin{array}{c}\text { Garcia, } \\
2016\end{array}$ & 1 & $\mathrm{~F}$ & UA, Mural & $\begin{array}{l}\text { Enucleation+ } \\
\text { extraction of } 48\end{array}$ & 1 year & - \\
\hline \multirow[t]{2}{*}{$\begin{array}{l}\text { Laborde, } \\
2016\end{array}$} & \multirow[t]{2}{*}{27} & \multirow[t]{2}{*}{$16 \mathrm{M}, 11 \mathrm{~F}$} & \multirow[t]{2}{*}{ Solid/Multicystic } & Radical: 11 & \multirow[t]{2}{*}{-} & $\begin{array}{l}\text { Conservative } \\
: 10\end{array}$ \\
\hline & & & & Conservative: 16 & & Radical: 1 \\
\hline \multirow[t]{2}{*}{ Haq, 2016} & \multirow[t]{2}{*}{31} & \multirow[t]{2}{*}{$13 \mathrm{M}, 18 \mathrm{~F}$} & \multirow[t]{2}{*}{ UA, Solid } & Radical:4 & \multirow{2}{*}{$\begin{array}{l}\text { 3-156 } \\
\text { months }\end{array}$} & \multirow[t]{2}{*}{ Primary: 3} \\
\hline & & & & Conservative: 27 & & \\
\hline Kim, 2017 & 1 & $\mathrm{~F}$ & UA & $\begin{array}{l}\text { Marsupialization }+ \\
\text { spontaneous } \\
\text { eruption of second } \\
\text { molar+ enucleation }\end{array}$ & $\begin{array}{c}49 \\
\text { months }\end{array}$ & - \\
\hline Kim, 2018 & 3 & $2 \mathrm{M}, 1 \mathrm{~F}$ & UA & $\begin{array}{l}\text { Decompression }+ \\
\text { Enucleation, } \\
\text { Enucleation }\end{array}$ & $\begin{array}{c}4 \\
\text { months } \\
\text { to } 1 \\
\text { year }\end{array}$ & - \\
\hline Ohiro, 2018 & 1 & M & $\begin{array}{c}\text { Solid } \\
\text { Ameloblastoma }\end{array}$ & Modified Dredging & $\begin{array}{c}13 \\
\text { years }\end{array}$ & - \\
\hline $\begin{array}{l}\text { Isolan, } \\
2018\end{array}$ & 1 & M & UA & $\begin{array}{l}\text { Marsupialization+ } \\
\text { enucleation } \\
\text { extraction of } 48\end{array}+$ & $\begin{array}{c}13 \\
\text { years }\end{array}$ & - \\
\hline $\begin{array}{l}\text { Zheng, } \\
2019\end{array}$ & 116 & $\begin{array}{l}\text { P-value: } \\
0.911\end{array}$ & UA & $\begin{array}{l}\text { Marsupialization+ } \\
\text { extraction of } \\
\text { affected teeth (if } \\
\text { present)+ } \\
\text { curettage+ }\end{array}$ & 5 years & $12 \%$ \\
\hline
\end{tabular}




\begin{tabular}{|c|c|c|c|c|c|c|}
\hline & & & & $\begin{array}{l}\text { peripheral } \\
\text { ostectomy }\end{array}$ & & \\
\hline $\begin{array}{c}\text { Rikhotso, } \\
2019\end{array}$ & 1 & M & Type II UA & $\begin{array}{l}\text { Enucleation+ } \\
\text { Peripheral } \\
\text { Ostectomy }\end{array}$ & 3years & - \\
\hline \multirow{3}{*}{$\begin{array}{c}\text { Dandriyal, } \\
2020\end{array}$} & \multirow[t]{3}{*}{20} & \multirow[t]{3}{*}{$12 \mathrm{M}, 8 \mathrm{~F}$} & Unilocular-7 & Conservative -10 & \multirow{3}{*}{5 years } & $\begin{array}{c}\text { Conservative } \\
-6\end{array}$ \\
\hline & & & Multilocular- 5 & Radical- 10 & & Radical- 1 \\
\hline & & & Solid- 8 & & & \\
\hline
\end{tabular}

Table 1: Selected article for sample data collected.

\section{Result}

56 articles were selected overall and 49 have been used for formatting of the present review. The exclusion criteria include any non-original articles, articles that include other types of Odontogenic tumours, evidence containing animal studies etc. The selected articles are categorized into 19 case reports, 7 retrospective case studies, 7 retrospective studies, 6 reviews, 6 systematic review articles and others. Out of these, 16 articles have been tabulated (Table 1) according to the Author, year, Gender of the patient, type of Ameloblastoma, its management, the follow-up and presence of recurrence, if any.

\section{Discussion}

Ameloblastoma was first recognised by Cusack in 1827 [13]. Initially named Adamantinoma by Malassez, in the 1930s, it was later renamed Ameloblastoma by Churchill [14]. Clinically, it may be quite variable in its presentation starting from a simple toothache or a loose tooth to an intraoral mass. There have been cases where the condition was identified secondary to other radiographic findings [15]. Earlier researches with respect to the treatment of Ameloblastoma are essentially based on case reports, retrospective reviews and histological evidence. A systematic review by Almeida, et al., in 2015 substantiated that the treatment of patients presenting with the lesion should be based on a combination of accurate routine radiographs and special imaging like Computed Tomography (CT) [16]. A representative biopsy reviewed by an oral or a general pathologist familiar with odontogenic lesions is necessary for determining the histological type [17]. Management of Ameloblastoma is still a controversy owing to its unique biological behaviour as a slow-growing, locally invasive tumour with a high rate of recurrence [9,11,17-21]. The current review will elaborate on the different types of management and their role in treating Ameloblastoma, emphasising on conservative treatment modalities. 
The current norms in the management of Ameloblastoma are to abide by resection, owing to the lower recurrence rate of $0-21 \%$ as mentioned by Labrode, et al., in 2017 [2]. Radical resection can be segmental, marginal resection or hemimandibulectomy with a clear margin of 1-2 cm [20]. This surgical approach leads to facial deformity, morbidity of the surgical site, functional disability ultimately compromising the patient's standard of living [21]. This more often results in psychological and social impediment. Evidently, these adversities can be confronted by reconstruction following resection. Though these issues can be tackled to a better extent this way, it entails additional surgery, is prohibitively expensive and may result in malocclusion and abnormal jaw movements [21,22].

The conservative approach is usually considered for lesions that are localised, within the cortical bone and do not have soft tissue involvement. One of the earliest evidence in literature for conservative management employed in treating Ameloblastomas dates back to 1928 by Simmons [23]. The conservative treatment modality does not affect the aesthetics of the patient, utilises the inherent osteogenic potential, reduces the surgical site morbidity and provides the patient with better living conditions. These features enable the procedure to be used in children and adolescents. When compared with adults, the paediatric age group has different bone physiology (more cancellous bone, increased turnover rate, reactive periosteum) and continuing facial growth, which responds positively to this type of management. In case of patients with unerupted teeth treated with conservative management, eruption of those teeth were unhindered and their vitality preserved $[8,24]$. The major drawback of this method is its higher recurrence rate when compared with radical approach, which is approximately 29.393\% according to the retrospective study by Labrode, et al., 2017 on the management and recurrence rate of Ameloblastomas [2].

The conservative approach is a two-step process with a primary procedure followed by an adjunctive aid that reduces the recurrence rate. Conservative management encompasses primary treatment involving Enucleation, Marsupialization or curettage and adjunctive therapy like the use of Carnoy's solution, Peripheral Ostectomy, or Liquid Nitrogen Cryosurgery [812]. The adjunctive procedures are used with the intention of removing the possibly infiltrated Ameloblastic cells from the surroundings of the lesion, providing a margin clear of tumour cells. This procedure aids in the growth of new bone and reduces the chances of recurrence. It has been reported that most of the recurrences with respect to Ameloblastoma following either resection or conservative therapy occurs within 5-10 years of treatment; hence a minimum follow up period of 5 years is considered essential [16].

Marsupialization or decompression is a technique employed in treating very large cysts, with close approximation to vital structures. Its aim is to reduce the size of the tumour for a less elaborate excision procedure and promote bone remodelling along with osteogenesis [24]. It is almost always followed by Enucleation. The reduced tumour is removed along with its lining Gurram P | Volume 3; Issue 1 (2022) | JDHOR-3(1)-038 | Review Article 
epithelium in this process. On the other hand, Curettage is the excavating or morcellation of the brittle portion of the lesion while preserving the bony continuity [25]. These primary procedures are accompanied by adjunctive procedures. Peripheral ostectomy is one of the options for an adjuvant procedure, wherein a margin of 2-3 $\mathrm{mm}$ of the surrounding uninvolved bone is removed [26]. Further, it has been recommended that following Enucleation and Peripheral ostectomy, the use of Carnoy's solution can reduce the recurrence rate of the tumour to a greater extent [27]. Carnoy's was initially used in 1933 by Zollinger and Cutler for chemical cauterization of cysts, with an ability to penetrate tissues at $1.54 \mathrm{~mm}$ in 5 minutes. It is a potent hemostat, a tissue fixative and cauterizing agent [28]. Another prevalent method is the use of cryosurgery in treating the tumor conservatively. It was first introduced in 1966 when cryosurgery was performed on dog femora. The first use of it in treating Ameloblastoma was in 1977 . The aim of the procedure is eliminating abnormal bone by freezing and devitalizing the bone segments. Liquid Nitrogen which has a temperature of $-196^{\circ} \mathrm{C}$ was considered appropriate. It is available in 4 forms: Liquid Nitrogen coil, Probe alone, Probe plus watersoluble jelly and Liquid Nitrogen spray. The latter two are used widely for their ease of use, rapid action and effectiveness [29]. The technique is cost-effective, easy to perform, the surgeon has better control on the procedure and the chances of injury to surrounding tissues is lower when compared to other techniques [30]. In 1973, yet another method came into existence called the "Dredging method", by Kawamura and Inoue [31]. This technique involved decompression and enucleation followed by repeated dredging with intervals of 2-3 months between each dredging. It is done to remove the scar tissue formed after the decompression procedures and accelerate new bone growth. Follow up begins if there's absence of tumour cells after 2 consecutive appointments [32]. This method eradicates the tumour while restoring the inherent function and esthetics of the involved bone.

All these adjunctive procedures should be performed with care, as they have their own limitations which could end up in the form of complications following the procedure. With peripheral ostectomy, while removing the surrounding bone with a rotary instrument, chances of embedment of the tumour cells into tumour-free spaces are higher, resulting in multiple satellite recurrence [26]. When we consider Carnoy's solution, it was found to be carcinogenic and was banned in 2013, by the FDA. This was due to the presence of Chloroform as one of its constituents. So, the use of modified Carnoy's for treating the tumour was taken into account. In a retrospective review by Dashow, 2015 on comparison between Carnoy's and Modified Carnoy's in Keratocystic Odontogenic Tumor, he reported a 3 fold increase in the recurrence following the use of Modified Carnoy's [33]. According to literature, the use of Carnoy's yields the best result with a reduced recurrence rate of $16 \%$ in Ameloblastomas when compared with other adjunctive procedures [34]. Carnoy's solution is strictly contraindicated in lesions which are in close proximity to the vital structures as it leads to detrimental effects. The complications following Liquid Nitrogen Cryosurgery primarily include wound dehiscence, paresthesia (when close to vital structures), infections and pathological fractures, due to its very high

Gurram P | Volume 3; Issue 1 (2022) | JDHOR-3(1)-038 | Review Article

Citation: Gurram P, et al. Role of Conservative Management in Treating Ameloblastoma of Jaw Bones:

A Review of Literature. J Dental Health Oral Res. 2022;3(1):1-13.

DOI: http://dx.doi.org/10.46889/JDHOR.2022.3101 
freezing temperature $\left(-196^{\circ} \mathrm{C}\right)$ as it results in vascular stasis and cell death. For this reason, a gas combination of Propane, Butane and Isobutane has been suggested, as the combined temperature is $-50^{\circ} \mathrm{C}$, which can decrease the risk of adverse reactions [30]. In a study by Fregnani, et al., in 2010, a recurrence rate of $31 \%$ was reported following curettage and cryotherapy, similar to that of Curi, et al., (30.6\%) [35]. The available literary evidence suggests that the dredging method, concedes a low recurrence rate of $16 \%$. Despite being a conservative technique, it is a time-consuming procedure, and the patient may or may not be ready for such an arduous approach [36].

Considering the different kinds of Ameloblastomas and their management, Peripheral Ameloblastoma is an extremely rare variant (1-2\% of all reported cases) which has minimal to no bone involvement, aiding to localised excision as the treatment of choice [37]. The solid/ multi-cystic variant is considered to be locally more aggressive due to their capacity to infiltrate the surrounding bone and evidently has a recurrence rate of $8 \%$ and $38 \%$ following radical and conservative approach respectively [37,38]. Hence, radical approach is more favoured. According to a systematic review by Almeida, et al., 2015, on the recurrence rate following treatment for primary multicystic Ameloblastoma, a 3.15 fold increase was observed when the lesions were managed conservatively and the outcomes were statistically significant [16]. However, Sadat, et al., 2011, utilised "Dredging Method" in treating Ameloblastoma and conferred positive outcomes with 3 primary recurrences out of 24 cases treated via dredging [32]. Evidence suggests that subtypes like follicular, plexiform or granular cell variants are only of histological significance and they do not determine the treatment or the prognosis [39]. The desmoplastic variant, is again, considered to be an uncommon variant (0.9-13\%), with incidences pertaining to the anterior jaw and mostly in the maxilla. They can occur either intraosseously or peripherally. Peripheral DAs are similar to Peripheral Ameloblastoma, therefore can be treated conservatively whereas, the intraosseous variety is considered to be potentially aggressive. It has been suggested that Intra-osseous variety tends to recur upon conservative management due to its aggressive nature. Thus, it is preferred to treat the tumor through excision with adequate margins [40].

Unicystic Ameloblastoma (UA) is comparatively less aggressive. Cystic lesions that shows clinical, radiographic or gross features of mandibular cyst and histological features depicting presence of a single cystic sac lined by ameloblastic epithelium are the criteria for diagnosing UA $[41,42]$. Evidence suggests that UA responds progressively to conservative techniques $[25,43,44]$. UA, is further classified into Luminal, Intraluminal and Mural on the basis of its ability to infiltrate the connective tissue layer of the cyst $[45,46]$. According to a case report by Gracia, et.al, in 2016, the mural variant infiltrates the connective tissue of the cyst. Due to this, it has higher chances of recurrence, following conservative management, hence extensive management is considered appropriate. The luminal and intraluminal types can be considered for a more conservative approach $[45,46]$. In a systematic review conducted by Lau and Gurram P | Volume 3; Issue 1 (2022) | JDHOR-3(1)-038 | Review Article 
Samman in 2006, the recurrence rate following various methods of treating UA, were stated as (I) Enucleation- 30.5\%, (II) Marsupialization- 18\%, (III) Enucleation with Carnoy's- $16 \%$ and (IV) Radical resection- 3.6\% [34].

When dealing with Ameloblastomas of maxilla, a cancellous bone, it lacks the ability to confine the tumour, unlike the cortical mandibular bone. Due to the complex craniofacial relationship of maxilla, a considerable amount of difficulty while diagnosis is expected. In case of tumours occurring in the posterior border of the maxilla, the chances of spread beyond the maxillary boundaries are higher, making definitive treatment difficult. Evidence proves that the potential chance of recurrence following conservative management in the maxilla is more. The recurring tumour has an increased chance of spreading into the orbit, nasal cavity, maxillary and ethmoidal sinuses. Even though a radical treatment of Ameloblastoma can result in structural deformity in this highly invasive tumor, a partial or total maxillectomy is the treatment of choice requiring complex reconstruction $[25,47]$. Therefore, the use of conservative approach in mandibular Ameloblastomas is deemed more appropriate when compared to the maxillary counterparts.

Speculations about biomolecular changes involved in Ameloblastomas were put forth. By 2014, authors elucidated the presence of mutated proteins in Ameloblastomas. It was reported that cascade of proteins like Mitogen- Activated Protein Kinase (MAPK) underwent alterations that lead to the mutation of BRAF V600E. Mutation of Hedgehog pathways (SMO) was considered the second most common somatic mutation in occurrences. BRAF mutations were observed in younger patients, in the mandible and the SMO mutations were observed in older patients, in maxilla. According to a study by Fernandes et.al, in 2018, targeted therapy using Vemurafenib $960 \mathrm{mg}$ PO, twice daily was provided to a patient with recurrent Ameloblastoma for a period of one year for BRAF inhibition therapy. The patient procured positive outcomes with adequate tolerance to the medication $[48,49]$. Although the end results are positive, due to the lack of prospective studies supporting the obtained outcome, the study remains inconclusive. Nevertheless, the molecular analysis of Ameloblastoma is bound to bring in a better insight in the treatment of Ameloblastoma in the near future.

\section{Conclusion}

Conservative procedures can be used to treat simple UA and Multicystic Ameloblastoma in the Paediatric age group and young adults. Though the recurrence rates can only be reduced and not evaded completely, it provides the patient with a better quality of life. The selection of treatment depends on the medical history of the patient, age, the size and behaviour of the lesion, its position, the macroscopic and histological variants, experience of the surgeon and most of all, patient's choice of management. It is necessary to remember that not all lesions 
can be treated conservatively nor they need to be approached radically. The maximum success of the procedure shouldn't lead to over treatment of the lesion. A balanced judgement while selecting the type of procedure is of utmost importance.

\section{Conflict of Interest}

The authors declare no conflict of interest exists.

\section{References}

1. Bordoloi B, Jaiswal R, Siddiqui S, Singh RB. A history of evolution of special stains. Int J Med Lab Res. 2017;2(3):55-62.

2. Anderson J. An introduction to Routine and special staining. 2011;18:2014.

3. Bordoloi B, Jaiswal R, Siddiqui S, Tandon A. Health hazards of special stains. Saudi J Pathol Microbiol. 2017;2:175-8.

4. Dey P. Basic and advanced laboratory techniques in histopathology and cytology. Springer Singapore. 2018.

5. Wulff S, Hafer L, Cheles M, Stanforth DA. Guide to special stains. Fort Collins, Colorado, USA. 2004:41-2.

6. Culling CF, Allison RT, Barr WT. Cellular pathology technique. Elsevier. 2014.

7. Rosai J. Rosai and Ackerman's surgical pathology. 10 $0^{\text {th }}$ Ed. London: Mosby. 2011.

8. Feulgren R, Rossenbeck H. Mikroskopisch-chemischer Nachweis einer Nucleinsäure vom Typus der Thymonucleinsäure und die-darauf beruhende elektive Färbung von Zellkernen in mikroskopischen Präparaten.1924;203-48.

9. Bauer H. Die Feulgensche Nuklealfärbung in ihrer Anwendung auf cytologische Untersuchungen. Zeitschrift für Zellforschung und Mikroskopische Anatomie. 1932;15:225-47.

10. Bancroft JD, Cook HC. Manual of histological techniques and their diagnostic application. Churchill Livingstone. 1994.

11. Bancroft JD, Gamble M, editors. Theory and practice of histological techniques. Elsevier Health Sci. 2008.

12. Van Gieson J. Laboratory notes of technical methods for the nervous system. NY Med J. 1889;50:57-60.

13. Lillie RD, Ashburn LL. Supersaturated solutions of fat stains in dilute isopropanol for demonstration of acute fatty degeneration not shown by Herxheimer's technique. Arch Pathol. 1943;36:432-40.

14. Highley JR, Sullivan N. Neuropathology and muscle biopsy techniques. Bancroft's Theory and practice of histological techniques, Suvarna, SK. 2019:306-36.

15. Bielschowsky M. Eine Modifikation meines Silberimprägnations-verfahrens zur Darstellung der Neurofibrillen. J Psychol Neurol. 1909;12:135-7.

16. Morris GB, Ridgway EJ, Suvarna SK. Traditional stains and modern techniques for demonstrating microorganisms in histology. Bancroft's Theory and Practice of Histological Tech. 2019:254-79.

17. Lendrum AC. The phloxin-tartrazine method as a general histological stain and for the demonstration of inclusion bodies. J Pathol Bacteriol. 1947;593:399-404.

18. Orchard GE. Pigments and minerals. Bancroft's Theory and practice of histological techniques e-book. 2018:198.

19. Perls M. Nachweis von Eisenoxyd in gewissen Pigmenten. Archiv für pathologische. Archiv $\mathrm{f}$ pathol Anat. $1867 ; 39: 42-8$.

20. Fontana A. Verfahren zur intensiver und raschen Farbung des Treponema pallidum und anderer Spirochäten. Dermatol Wochenschr. 1912;55:1003-4.

21. Masson P. La glande endocrine de l'intestin chez l'homme. CR Acad Sci (Paris). 1914;158:59-61.

Gurram P | Volume 3; Issue 1 (2022) | JDHOR-3(1)-038 | Review Article 
22. McGee-Russell SM. Histochemical methods for calcium. J Histochemis Cytochem. 1958;6(1):22-42.

23. McMANUS JF. Histological demonstration of mucin after periodic acid. Nature. 1946;158:202.

24. Southgate HW. Note on preparing mucicarmine. J Pathol Bacteriol. 1927;30(4):729.

25. Picken MM, Herrera GA. Thioflavin T stain: an easier and more sensitive method for amyloid detection in amyloid and related disorders. Humana Press, Cham. 2015;225-27.

26. Puchtler H, Sweat F, Kuhns JG. The binding of direct cotton dyes by amyloid. J Histochem Cytochem. 1964;12:900-7.

27. Glenner GG. Amyloid deposits and amyloidosis. The beta-fibrilloses (first of two parts). N Engl J Med. 1980;302(23):1283-92.

28. Gilbertson JA, Tennent GA, Botcher NA. Histological diagnosis of amyloid - problems and solutions. The Biomedical Scientist. 2015;59:628-9.

29. Highman B. Improved methods for demonstrating amyloid in paraffin sections. Arch Pathol (Chic). 1946;41:559-62.

30. Wintrobe MM. Wintrobe's clinical hematology. $13^{\text {th }}$ Ed. Lippincott Williams and Wilkins. 2008.

31. Idris AA, Hussain MS. Comparison of the efficacy of three stains used for the detection of cytological changes in Sudanese females with breast lumps. Sudan. J Public Health. 2009;4(2):275-7.

32. Garbyal RS, Agarwal N, Kumar P. Leishman-Giemsa cocktail: an effective Romanowsky stain for air-dried cytologic smears. Acta Cytol. 2006;50(4):403-6.

33. Koss LG. Cytologic techniques, diagnostic cytology and its histopathologic basis, Carol E Bales. $5^{\text {th }} \mathrm{Ed}$ 2006;2:1592-601.

34. Power KT. The Romanowsky stains: a review. Am J Med Technol. 1982;48(6):519-23.

35. Suryalakshmi S, Thangamani P, Ravi S, Niveditha T, Kumar IV, Premalatha DR, et al. Comparision of leishman staining with H\&E staining technique in the study of FNAC smears. Int Organ Sci Res. 2016;15:349.

36. Krafts KP, Hempelmann E, Oleksyn BJ. The color purple: from royalty to laboratory with apologies to Malachowski. Biotech Histochem. 2011;86(1):7-35.

37. ICSH reference method for staining of blood and bone marrow films by azure B and eosin Y (Romanowsky stain). International Committee for Standardization in Haematology. Br J Haematol. 1984;57(4):707-10.

38. Dunning K, Safo AO. The ultimate Wright-Giemsa stain: 60 years in the making. Biotech Histochem. 2011;86(2):69-75.

39. Li CY. The role of morphology, cytochemistry and immunohistochemistry in the diagnosis of chronic myeloproliferative diseases. Int J Hematol. 2002;76(2):6-8.

40. Hayhoe FG. Cytochemistry of the acute leukaemias. Histochem J. 1984;16(10):1051-9.

41. Jaffe R. WHO classification of tumours of haematopoietic and lymphoid tissues. World Health Organization Classification of Tumours. 2008:358-60.

42. Chen M, Wang J. Gaucher disease: review of the literature. Arch Pathol Lab Med. 2008;132(5):851-3.

43. Goel G, Halder A, Joshi D, Anil AC, Kapoor N. Rapid, Economic, Acetic Acid Papanicolaou stain (REAP): an economical, rapid, and appropriate substitute to conventional pap stain for staining cervical smears. J Cytol. 2020;37(4):170-3.

44. Gill GW. Papanicolaou stain. In: cytopreparation. Essentials in cytopathology. Springer. 2013:12.

45. Dey P. Routine Staining in Cytology Laboratory. In: basic and advanced laboratory techniques in histopathology and cytology. Singapore. Springer. 2018.

46. Drury RA, Wallington EA. Carleton's histological technique $5^{\text {th }}$ Ed. New York: Churchill Livingstone. 1980.

47. Cook HC, Bancroft JD, Stevens A. Theory and practice of histological techniques. In Carbohydrates. Churchill Livingstone. 1982;180-216.

48. Bagalad BS, Mohan Kumar KP. Vital staining: clinical tool in discovering oral epithelial dysplasia and carcinoma-overview. J Dent Pract Res. 2013;1:34-8. 
49. Culling CF, Allison RT, Barr WT. Haematoxylin and its counterstain. In cellular pathology technique. $4^{\text {th }}$ Ed. Butterworth-Heinemann. 1985;111-52.

50. Epstein JB, Oakley C, Millner A, Emerton S, van der Meij E, Le N. The utility of toluidine blue application as a diagnostic aid in patients previously treated for upper oropharyngeal carcinoma. Oral Surg Oral Med Oral Pathol Oral Radiol Endod. 1997;83(5):537-47.

51. Gandolfo S, Pentenero M, Broccoletti R, Pagano M, Carrozzo M, Scully C. Toluidine blue uptake in potentially malignant oral lesions in vivo: clinical and histological assessment. Oral Oncol. 2006;42(1):8995.

52. Salati NA, Khwaja JK, Aggarwal A, Asdullah M, Khan MH, Gupta J. Diagnostic and prognostic potential of special stains in oral epithelial dysplasia-a clinicopathologic study. University J Dent Sci. 2018;4:57-61.

53. Sankaranarayanan R, Wesley R, Thara S, Dhakad N, Chandralekha B, Sebastian P et al. Test characteristics of visual inspection with $4 \%$ acetic acid (VIA) and Lugol's iodine (VILI) in cervical cancer screening in Kerala, India. Int J Cancer. 2003;106(3):404-8.

54. Du GF, Li CZ, Chen HZ, Chen XM, Xiao Q, Cao ZG, et al. Rose bengal staining in detection of oral precancerous and malignant lesions with colorimetric evaluation: a pilot study. Int $\mathrm{J}$ Cancer. 2007;120(9):1958-63.

55. Mittal N, Palaskar S, Shankari M. Rose Bengal staining - diagnostic aid for potentially malignant and malignant disorders: a pilot study. Indian J Dent Res. 2012;23(5):561-4.

56. Krishnanand PS, Kamath VV, Nagaraja A, Badni M. Artefacts in oral mucosal biopsies-a review. J Orofac Sci. 2010;2(1):57.

57. Grizzle WE, Stockard CR, Billings PE. The effects of tissue processing variables other than fixation on histochemical staining and immunohistochemical detection of antigens. J Histotechnol. 2001;24(3):213-9.

58. Kumar GL, Kiernan JA, Gill GW, Rashmil Saxena BF, Henwood A, Nowacek JM, et al. 08066 Special Stains Eduguide.

59. Eltoum I, Fredenburgh J, Myers RB, Grizzle WE. Introduction to the theory and practice of fixation of tissues. J Histotechnol. 2001;24(3):173-90. 